\title{
Biotechnological Potential of Aspergillus niger UCP 1353 and the Use of Activated Coal on the Discoloration of Dye Orange II
}

\author{
Lefferson C. Gomes ${ }^{1}$, Paulo H. da Silva ${ }^{1}$, Ana P. Melo bione ${ }^{2}$, Amanda B. Lins ${ }^{2}$, Tainã C.S. \\ Fonseca $^{2}$, Rosileide F.S. Andrade ${ }^{3}$, Carlos A. da Silva ${ }^{3}$ and Galba M. Campos-Takaki ${ }^{*}$ \\ ${ }^{1}$ Chemical Engineering, Catholic University of Pernambuco, 50.050-900 Recife, PE, Brazil \\ ${ }^{2}$ Enviromental Process Development, Catholic University of Pernambuco, \\ 50.050-900 Recife, PE, Brazil \\ ${ }^{3}$ Nucleus of Research in Environmental Sciences and Biotechnology, Catholic University of \\ Pernambuco, 50.050-590 Recife, PE, Brazil
}

*Corresponding author

\section{A B S T R A C T}

\begin{abstract}
Keywords
Biological agents.

Textile effluent.

Aspergillus niger.

Fungal biomass.

Activated carbon.

Article Info

Accepted:

19 October 2017

Available Online:

10 December 2017 from Caatinga soil of Pernambuco (PE, Brazil), evaluating his development in the carbon (glucose and agro whey residue) and nitrogen (peptone and glutamic acid) sources to biomass production. To qualify discoloration Orange II from the adsorption process, the inactivated biomass of different concentrations $(0.1$ to $0.5 \mathrm{~g})$ were added to the dye for $24 \mathrm{~h}$ at $150 \mathrm{rpm}$ and $30^{\circ} \mathrm{C}$ tests in comparison with activate charcoal. The most biomass production $94.1 \mathrm{~g} \mathrm{~L}^{-1}$ was occurred using whey, peptone and glutamic acid $(15 \mathrm{ml}: 10 \mathrm{~g}$ : $\left.1 \mathrm{~g} . \mathrm{L}^{-1}\right)$. The dye discoloration results showed a rate of $66 \%$ for $0.5 \mathrm{~g} . \mathrm{L}^{-1}$ of biomass concentration in contact $8 \mathrm{~h}$, and the greater adsorption capacity of $2.26 \mathrm{mg} \cdot \mathrm{g}^{-1}$ to $0.1 \mathrm{~g} . \mathrm{L}^{-1}$ biomass for $24 \mathrm{~h}$. However, the comparison with the charcoal showed greater discolouration efficiency $(100 \%)$ in contact of $8 \mathrm{~h}$. Thus, the experimental data for the adsorption Orange II dye, shown that the activate carbon has a more efficient removal compared to the fungal biomass. Despite these results, the use of fungal biomass in wastewater treatment processes can be made possible considering the reduction of the costs of production using agro-industrial waste.
\end{abstract}

The objective of this study was to evaluate growth of Aspergillus niger UCP 1353 isolated

\section{Introduction}

The environmental problems have become increasingly frequent, reaching in some regions to a critical situation, one of the reasons that contributes for this to occur in the industrial activities. Among these activities, the textile effluents stand out because they are strongly colored due to the presence of dyes that do not bind to the fiber during the dyeing process (Kunzet al., 2002; Favere et al., 2010;
Salvador et al., 2012). According to Sousa and Zamora (2005), the fact that they use large amounts of water associated with the low utilization of the inputs (dyes, detergents, gummings, softeners and others), makes the textile industry responsible for the large generation of waste volumes, with high organic load and strong staining. Dyes and pigments are compounds widely used in the 
textile, food, paper, pharmaceutical, cosmetic and other industries (Beydilli and Pavlostathis, 2005). Among these the azo dyes, composing $70 \%$ of the dyes produced in this way, having a great participation in the contamination of aquatic effluents (Barreto $e t$ al., 2011). These azo dyes can be transformed or degraded by a variety of microorganisms, including aerobic and anaerobic bacteria and fungi (Banatet al., 1996; Chang and Kuo, 2000; Singh et al., 2014).

However, recent studies indicate that some factors may influence the removal of synthetic dyes during the activity of microbial discoloration. They are nutritional factors (carbon and nitrogen sources) and physical (temperature, $\mathrm{pH}$ and agitation) that can affect the degradation of azo dyes (Mielgo et al., 2001; Singh et al., 2014).

One of the main physicochemical techniques used in the removal of dye substances is adsorption, a phenomenon of mass transfer of a solute (adsorbate), present in a fluid phase, to the porous surface of a solid phase (adsorbent), through physical or chemical interaction of the molecules of the solute with the surface of the adsorbent (solid) (Conceição and Freire, 2013).

Recently, several researches have indicated that fungi have the ability to discolor and remove textile dyes by biosorption (Peixoto et al., 2013). Aspergillus niger is a haploid filamentous fungus, found in soil, plants and air, considered one of the most important microorganisms used in biotechnology. Niger species have proven efficiency in the degradation of recalcitrant effluent compounds from various industries such as pharmaceuticals, olive oil, breweries, among others (Santaella et al., 2009; Deepika et al., 2014). Also its characteristic is the use of dyes as substrate turning them into non-toxic compounds, or of low toxicity.
The objective of this study was to discolor azo reactive dye by the physical-chemical method of adsorption by activated carbon and by biological adsorbent through the biosorption technique, analyzing the effect of carbon sources on biomass production by Aspergillus niger and its application in discoloration and degradation of the orange dye azole II.

\section{Materials and Methods}

\section{Microorganism and maintenance media}

The Aspergillus niger UCP 1353, isolated from the Caatinga soil of Pernambuco, was kept in test tubes containing Sabouraud culture medium (SAB) stored at $5^{\circ} \mathrm{C}$. Samples were inoculated into Petri dishes containing the $\mathrm{SAB}$ medium for preparation of the preinoculum for 7 days at $28^{\circ} \mathrm{C}$.

After this interval, the spores were collected, with the aid of sterile swabs, previously moistened with sterile water, and the number of spores in Neubauer's chamber was determined. Aliquots of $10 \mathrm{~mL}$ spore suspension containing $10^{7}$ spores $/ \mathrm{mL}$ were used as pre-inoculum.

\section{Determination of biomass production by Aspergillusniger}

The microorganism was inoculated in $100 \mathrm{~mL}$ of $\mathrm{SAB}$ liquid medium containing different sources of carbon g.. ${ }^{-1}$ (glucose $20 \mathrm{~g}$ and milk whey, 5, 10 and $15 \mathrm{~mL}$ ) and nitrogen (peptone $10 \mathrm{~g}$ and glutamic acid 1 $\mathrm{g}$ ), samples of mycelium collected after 96 hours, were washed twice with distilled and deionized ice water and subjected to the lyophilization process, and then kept in vacuum desiccator until constant weight. The dry weight value was used to establish the graph corresponding to the amount of biomass produced in each medium. 


\section{Inactivation of mycelium}

The mycelium obtained from the carbon and nitrogen sources analysis process was inactivated using 1\% formaldehyde solution (Faraco et al., 2009). After inactivation the mycelium was kept in a water bath $\left(100^{\circ} \mathrm{C}\right)$ for two hours, and then filtered and washed twice with distilled water and incubated $\left(50^{\circ} \mathrm{C}\right)$ for 24 hours to dry the inactivated biomass. It was then macerated with the help of a pistil and passed through $1 \mathrm{~mm}$ granulometric screens to standardize the particle size.

\section{Adsorption kinetics}

Different amounts of the inactivated mycelium, 0.1, 0.2, 0.3, 0.4, and $0.5 \mathrm{~g}$ were added in $250 \mathrm{ml}$ Erlenmeyer's flasks containing $100 \mathrm{ml}$ of the orange dye solution II $(0.025 \mathrm{mM})$ of an initial dye concentration of $8.8 \mathrm{mg} . \mathrm{L}^{-1}$, and active carbon tests under the same conditions were performed to compare the discoloration. The $\mathrm{pH}$ of the solutions was measured in potentiometer at the beginning and at the end of the process, with no variation remaining in the range of 5.0 for the control and all the tests performed.

The solutions were incubated in shaker $\left(150 \mathrm{rpm}, 28^{\circ} \mathrm{C}\right)$ in the absence of light. For the discoloration kinetics study, $2 \mathrm{~mL}$ aliquots were collected and centrifuged at $9000 \mathrm{rpm}$ for $6 \mathrm{~min}$ at 8,12 , and 24 hour intervals, and the control of the experiment was prepared without the mycelium and all the experiments performed in duplicate.

All absorbance readings were performed on UV-Visible spectrophotometer (Spectronic Genesis II) at wavelength of $485 \mathrm{~nm}$ (Ambrósio et al., 2012).

Removal of the dye was calculated by the following equation (Gupta et al., 2011).
Color removal $(\%)=\frac{\text { Abs control-Abs sample }}{\text { Abs control }}$

Where"Abs sample" represents the value of absorbance found after treatment and "Abs control" the value of the absorbance found of the reference solution.

\section{Orange dye calibration curve II}

The Table 1 shows the dilutions used to obtain the orange dye calibration curve, the dye volume that was used for each dilution, starting from a volume of $2 \mathrm{~mL}$, and the absorbance values. By these values the calibration curve was obtained and the equation of the line for the dye Orange II (Figure 1).

For the determination of the volume to be removed from the stock concentration of the orange solution II for the most diluted solution for the preparation of the calibration curve the following calculation was performed:

$\mathrm{C}$ stock $\mathrm{x} \mathrm{V}$ stock $=\mathrm{C}_{1} \times \mathrm{V}_{1}(2)$

Where " $\mathrm{C}$ " stock is the initial concentration of the orange dye solution II $\left(8.8 \mathrm{mg} . \mathrm{L}^{-1}\right)$, the "V" stock represents the desired volume of the stock solution of the dye for each dilution, " $\mathrm{C}_{1}$ " the desired concentration of the dye for each dilution and " $\mathrm{V}_{1}$ " indicates the volume of the solution $(2 \mathrm{~mL})$.

Using the spectrophotometer adsorption values, the equation of the line was obtained to calculate the concentration of the dye in the water:

$\boldsymbol{x}=\frac{\boldsymbol{y}-0.0164}{0.0670}$

Where " $y$ " is the absorbance value in spectrophotometer, and " $x$ " is concentration of dye in water. 
Calculation of the adsorption capacity " $q$ " (mg.g $\left.{ }^{-1}\right)$

To determine the adsorption of dye by mass of adsorbent at any time, the equation:

$q=\frac{V(c 0-C)}{m}$

Where the " $q$ " is the concentration of solute in the solid phase of adsorption capacity (mg. $\mathrm{g}^{-1}$ ), the "C 0 " the initial concentration of solute in the liquid phase $\left(\mathrm{mg} . \mathrm{L}^{-1}\right)$, the "C"Concentration at any given instant, the $\mathrm{m}$ represents the amount of adsorbent used, the " $\mathrm{m}$ " represents the amount of adsorbent used and the " $\mathrm{V}$ " is the volume da solution.

By the difference between the initial solute concentration in the liquid phase " $\mathrm{C} 0$ " (8, $\left.8 \mathrm{mg} . \mathrm{L}^{-1}\right)$ and the concentration at a given time "C", it is possible to determine how much was removed from the dye by the adsorbent.

\section{Results and Discussion}

\section{Biomass Production}

Figure 2 shows the amount of biomass produced by Aspergillus niger for each residue concentration in the medium after the 96 hour period.

Dye removal values and experimental "q" for the bioadsorbent.

Figure 3 shows the percentage amount that was removed from the dye azo for each test performed at a given time point by the fungal biomass.

Table 2 shows the values obtained for the removal of Orange II, the reduction of the concentration in the solution, the amount of dye removed and dye accumulation by amount of the biosorbent (q) for each test performed at a given time point.
Figures 4 and 5 show the dye concentration curves and the adsorption capacity of the dye in the solid phase for a given amount of the biosorbent, respectively, for each time instant.

Figure 5 represents the value of the solute concentration in the solid phase for a given amount of biomass at a given instant.

\section{Dye removal values and experimental " $q$ " for adsorbent activated carbon}

Figure 6 shows the removal of the orange dye II for each of the tests performed with activated charcoal at a given time point.

Table 3 presents the values of the concentration of the dye in the solution, the concentration of the dye removed, the value of $\mathrm{q}$ and the removal of the color for each test performed at each time point of the adsorbent activated carbon.

Figure 7 shows the calibration curves for the reactive Azo concentration for the tests conducted over time for the activated carbon. Figure 8 illustrates the sorption capacity of the solute for a given amount of active carbon in a given time. The use of different sources of carbon for biomass production by the isolated fungus Aspergillus niger showed that the residue whey influenced the increase of the biomass yield being corresponding to the concentration (Figure 2). Values of 94.1 g.L $\mathrm{L}^{-1}$ of biomass were obtained at the end of 96 hours of cultivation, being $79.3 \%$ more in relation to glucose.

In the fermentative processes for the production of biomass, the most important factors are the choice of the microorganism and the culture medium, the first in terms of its enzymatic arsenal (metabolism) and consequently the ability to synthesize the target product, the second, to enable and direct the metabolic pathways, resulting in possible yield changes (Melo et al., 2017). 
Table.1 Calculation of the standards for calibration curve of orange dye II

\begin{tabular}{ccccc}
\hline \multicolumn{2}{c}{ Itended } & \multicolumn{2}{c}{ SM Pipetting } & Absorbance \\
\hline $\mathrm{C}_{1}\left(\mathrm{mg} . \mathrm{L}^{-1}\right)$ & $\mathrm{V}_{1}(\mathrm{~mL})$ & Cstock $\left(\mathrm{mg} . \mathrm{L}^{-1}\right)$ & $\mathrm{V}$ stock $(\mathrm{mL})$ & Abs \\
8.8 & 2 & 8.8 & 2 & 0.606 \\
7.8 & 2 & 8.8 & 1.77 & 0.532 \\
6.8 & 2 & 8.8 & 1.54 & 0.432 \\
5.8 & 2 & 8.8 & 1.32 & 0.427 \\
4.8 & 2 & 8.8 & 1.09 & 0.339 \\
3.8 & 2 & 8.8 & 0.95 & 0.29 \\
2.8 & 2 & 8.8 & 0.64 & 0.202 \\
1.8 & 2 & 8.8 & 0.41 & 0.134 \\
0.8 & 2 & 8.8 & 0.18 & 0.059 \\
\hline
\end{tabular}

Table.2 Concentrations of dye in the solution and removed, q experimental and percentage of removal for each in different time interval and biomass

\begin{tabular}{cccccc}
\hline $\mathrm{T}$ (hours) & $\begin{array}{c}\text { Biomass } \\
(\mathrm{g})\end{array}$ & $\begin{array}{c}\text { Dye in } \\
\text { solution } \\
\left(\mathrm{mg} . \mathrm{L}^{-1}\right)\end{array}$ & $\begin{array}{c}\text { Removed } \\
\text { dye } \\
\left(\mathrm{mg} . \mathrm{L}^{-1}\right)\end{array}$ & $\begin{array}{c}\mathrm{q} \text { exp } \\
\left(\mathrm{mg} . \mathrm{g}^{-1}\right)\end{array}$ & $\begin{array}{c}\text { Removal } \\
(\%)\end{array}$ \\
\hline 0 & 0 & 8.8 & 0 & 0 & 0.00 \\
8 & 0.1 & 7.25 & 1.55 & 1.55 & 18.90 \\
12 & 0.1 & 6.93 & 1.87 & 1.87 & 22.37 \\
24 & 0.1 & 6.54 & 2.26 & 2.26 & 26.58 \\
8 & 0.2 & 6.38 & 2.42 & 1.21 & 28.27 \\
12 & 0.2 & 6.04 & 2.76 & 1.38 & 31.99 \\
24 & 0.2 & 6.06 & 2.74 & 1.37 & 31.74 \\
8 & 0.3 & 4.45 & 4.35 & 1.45 & 49.92 \\
12 & 0.3 & 4.38 & 4.42 & 1.47 & 51.78 \\
24 & 0.3 & 4.21 & 4.59 & 1.53 & 49.19 \\
8 & 0.4 & 3.75 & 5.05 & 1.01 & 58.80 \\
12 & 0.4 & 3.64 & 5.16 & 1.29 & 57.92 \\
24 & 0.4 & 3.56 & 5.24 & 1.31 & 56.79 \\
8 & 0.5 & 3.41 & 5.39 & 1.08 & 65.59 \\
12 & 0.5 & 3.26 & 5.54 & 1.11 & 62.04 \\
24 & 0.5 & 2.93 & 5.87 & 1.17 & 60.42 \\
\hline
\end{tabular}


Table.3 Concentrations of dye in the solution and removed, q experimental and percentage of removal for each in different time interval and active carbon

\begin{tabular}{cccccc}
\hline $\mathrm{t}$ (hours) & $\begin{array}{c}\text { Mass } \\
(\mathrm{g})\end{array}$ & $\begin{array}{c}\text { Dye in solution } \\
\left(\mathrm{mg} . \mathrm{L}^{-1}\right)\end{array}$ & $\begin{array}{c}\text { Dye removed } \\
\left(\mathrm{mg} . \mathrm{L}^{-1}\right)\end{array}$ & $\begin{array}{c}\mathrm{q} \text { exp } \\
\left(\mathrm{mg} . \mathrm{g}^{-1}\right)\end{array}$ & $\begin{array}{c}\text { Removal } \\
(\%)\end{array}$ \\
\hline 0 & 0 & 8.8 & 0 & 0 & 0 \\
8 & 0.1 & 2.49 & 6.3 & 6.31 & 70.44 \\
12 & 0.1 & 0.99 & 7.8 & 7.81 & 86.59 \\
24 & 0.1 & 0.00 & 8.8 & 8.8 & 100.00 \\
8 & 0.2 & 0.74 & 8.1 & 4.03 & 89.34 \\
12 & 0.2 & 0.00 & 8.8 & 4.4 & 98.06 \\
24 & 0.2 & 0.00 & 8.8 & 4.4 & 100.00 \\
8 & 0.3 & 0.34 & 8.5 & 2.82 & 93.70 \\
12 & 0.3 & 0.00 & 8.8 & 2.93 & 98.55 \\
24 & 0.3 & 0.00 & 8.8 & 2.93 & 100.00 \\
8 & 0.4 & 0.35 & 8.4 & 2.11 & 93.54 \\
12 & 0.4 & 0.00 & 8.8 & 2.2 & 100.00 \\
24 & 0.4 & 0.00 & 8.8 & 2.2 & 100.00 \\
8 & 0.5 & 0.00 & 8.8 & 1.76 & 99.35 \\
12 & 0.5 & 0.00 & 8.8 & 1.76 & 100.00 \\
24 & 0.5 & 0.00 & 8.8 & 1.76 & 100.00 \\
\hline
\end{tabular}

Fig.1 Orange dye calibration curve II

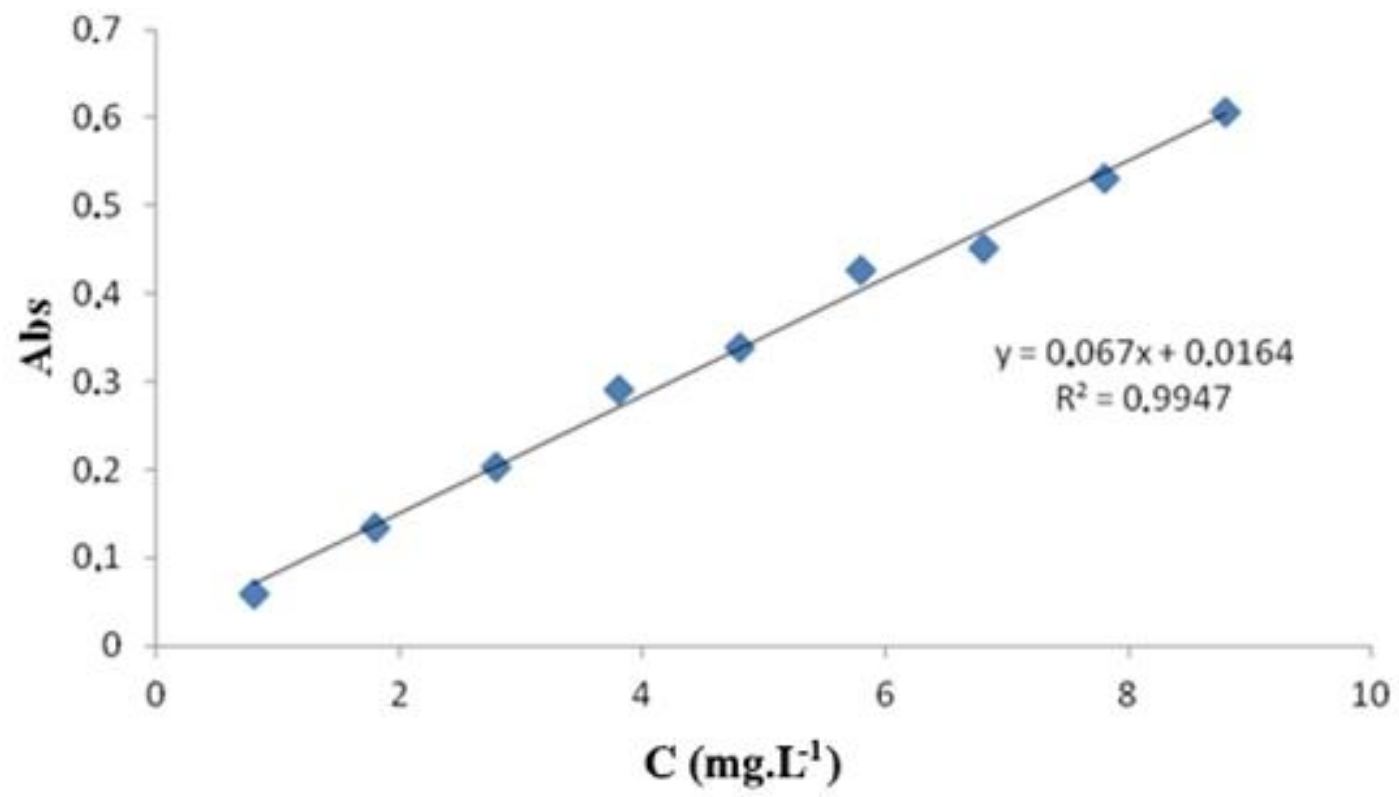


Fig.2 Production of biomass in the absence and presence of agroindustrial residue in different concentrations

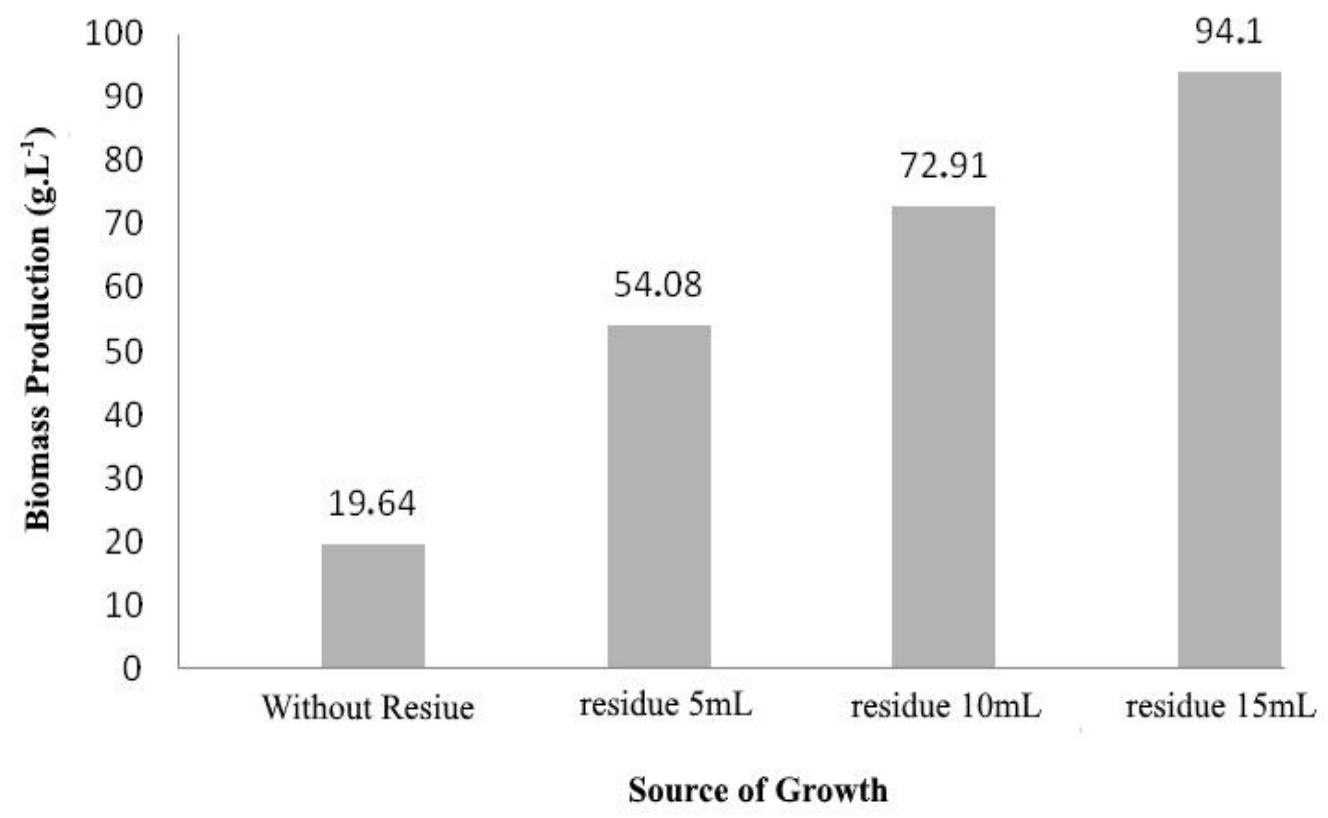

Fig.3 Efficiency of removal of the orange dye II, in a determined amount of biomass for a given time instant

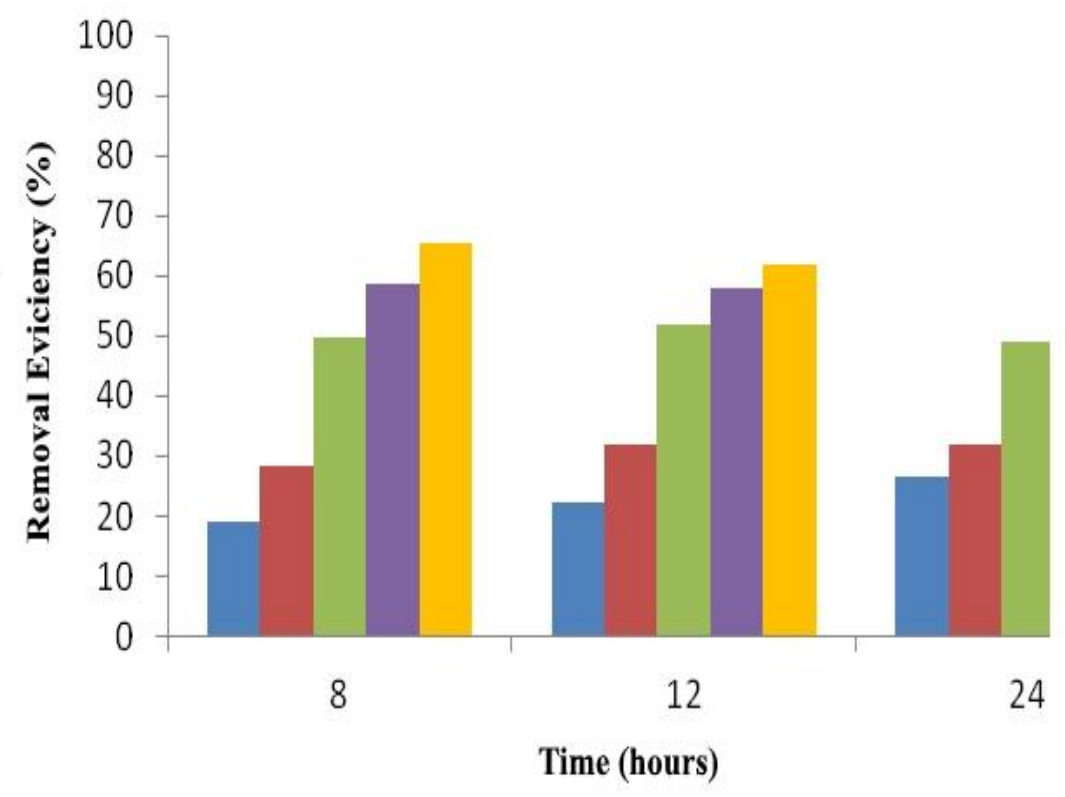

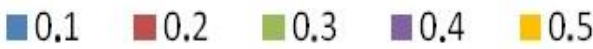


Fig.4 Concentration of dye in the solution for a given amount of biomass at a given instant

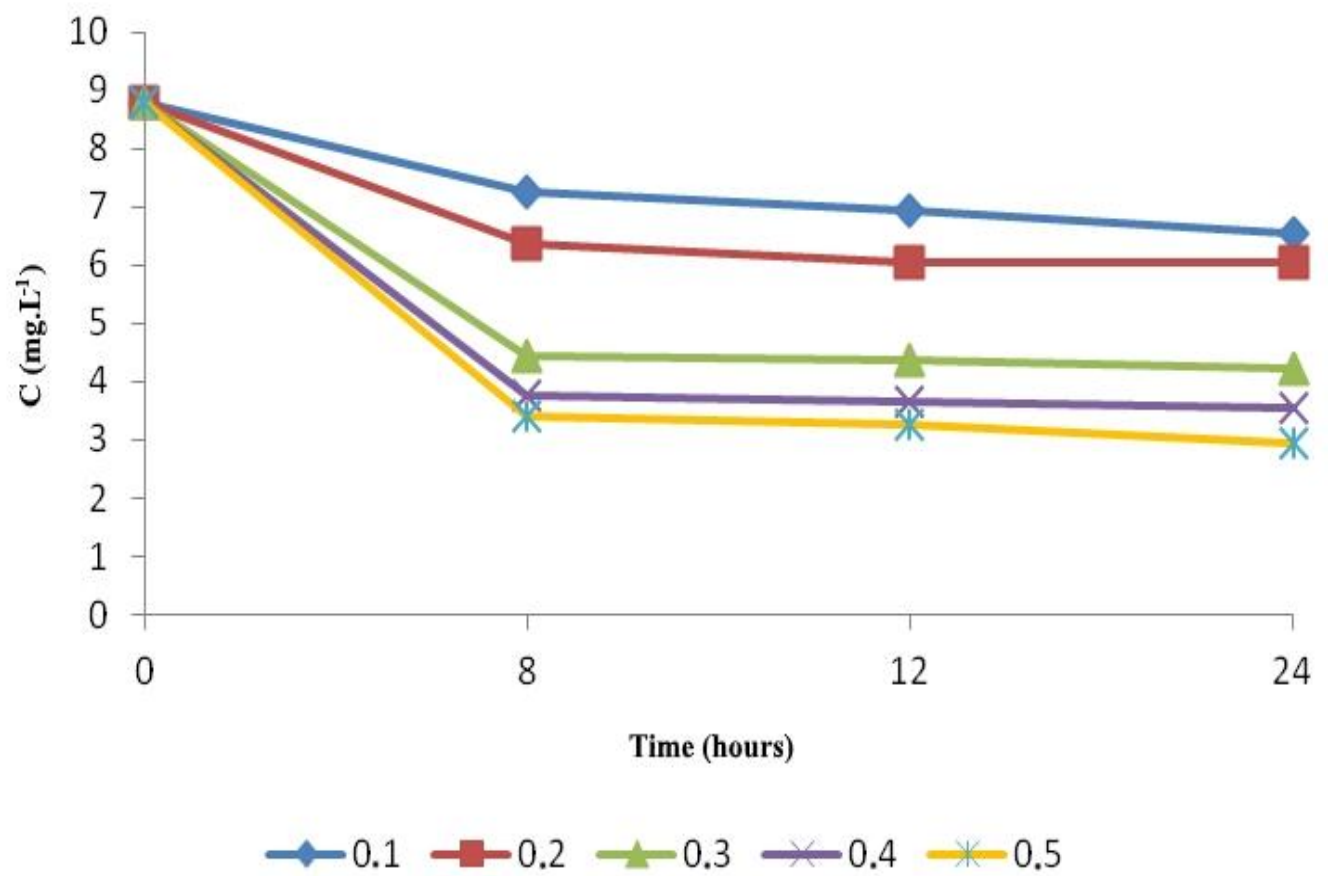

Fig.5 Value of the solute concentration in the solid phase for a given amount of biomass at a given instant

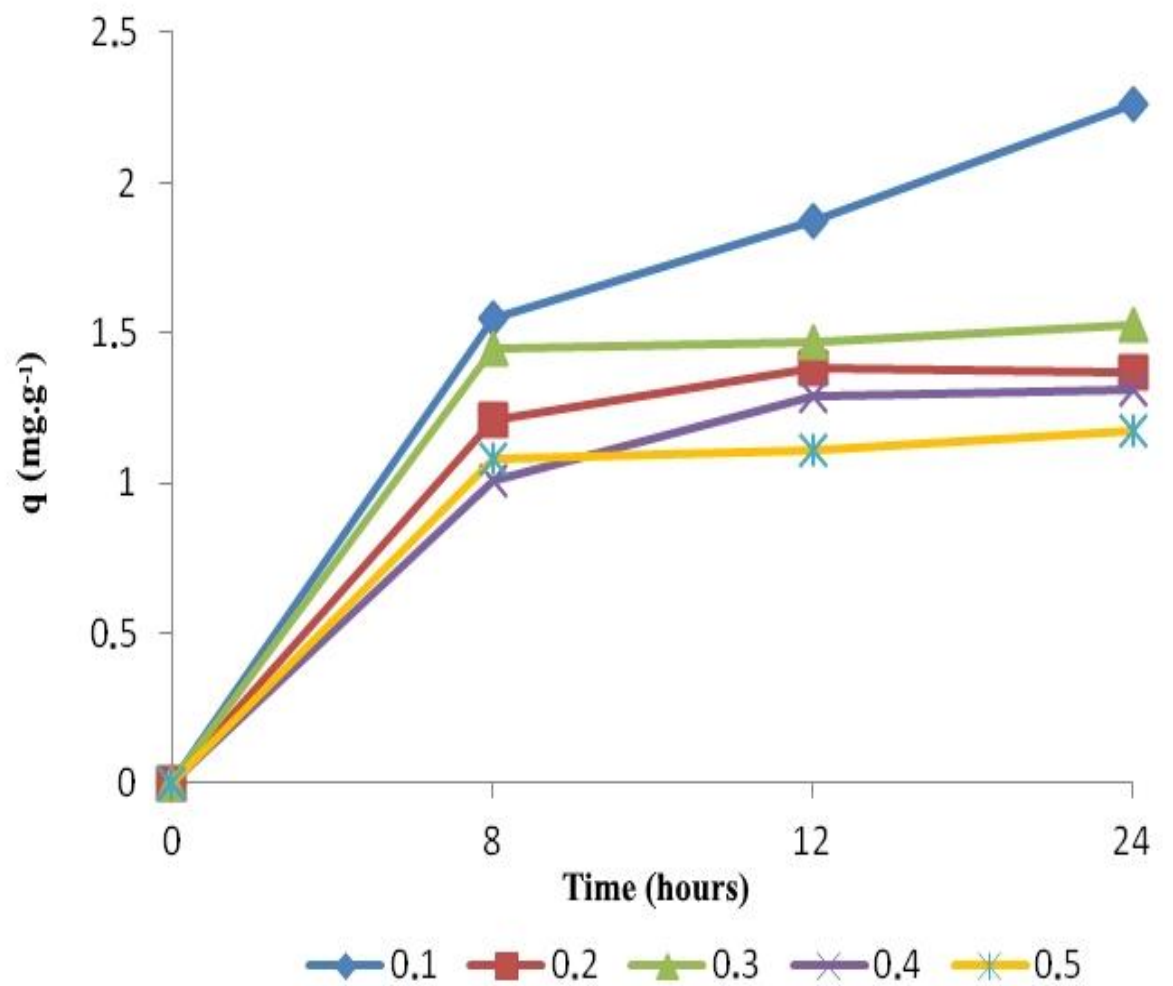


Fig.6 Efficiency of removal of the orange dye azo II for a determined amount of activated carbon at a certain instant of time

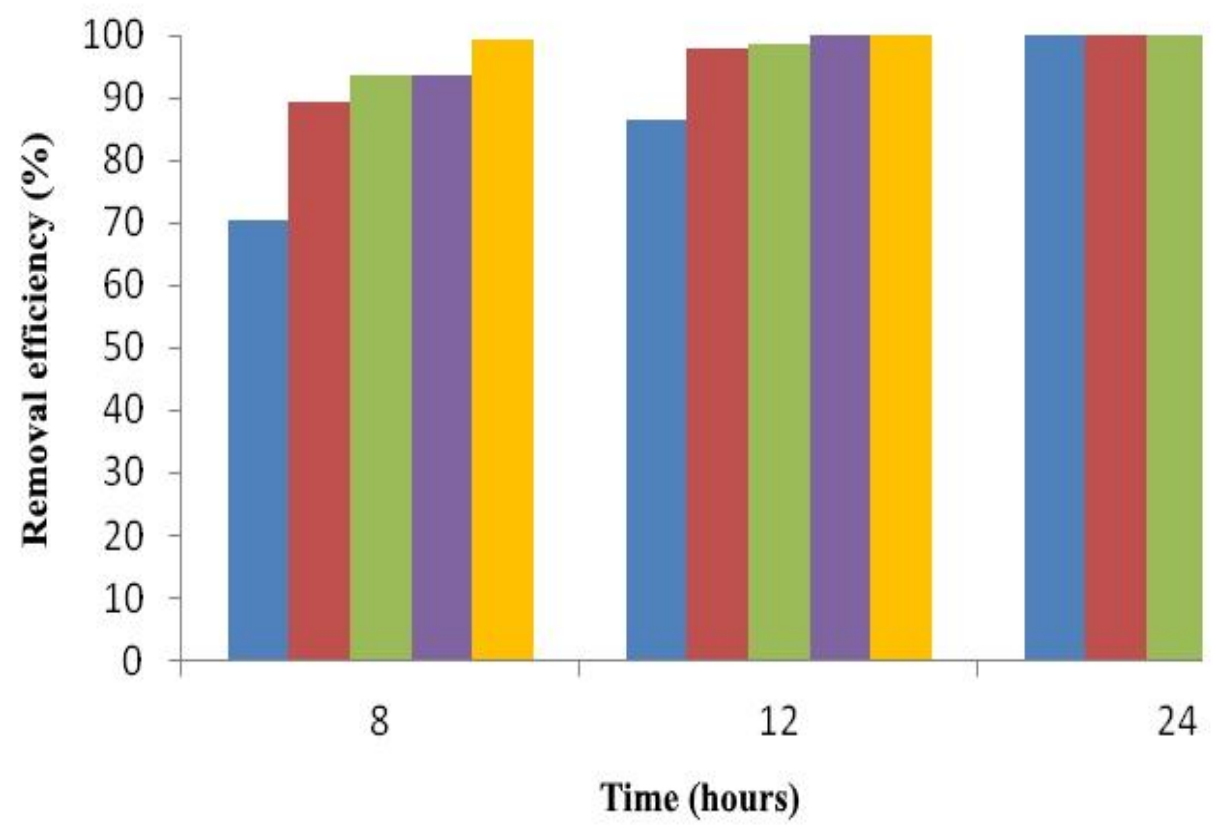

$\square 0.1 \square 0.2 \square 0.3 \square 0.4=0.5$

Fig.7 Dye concentration in the solution for a given amount of activated carbon at a given instant

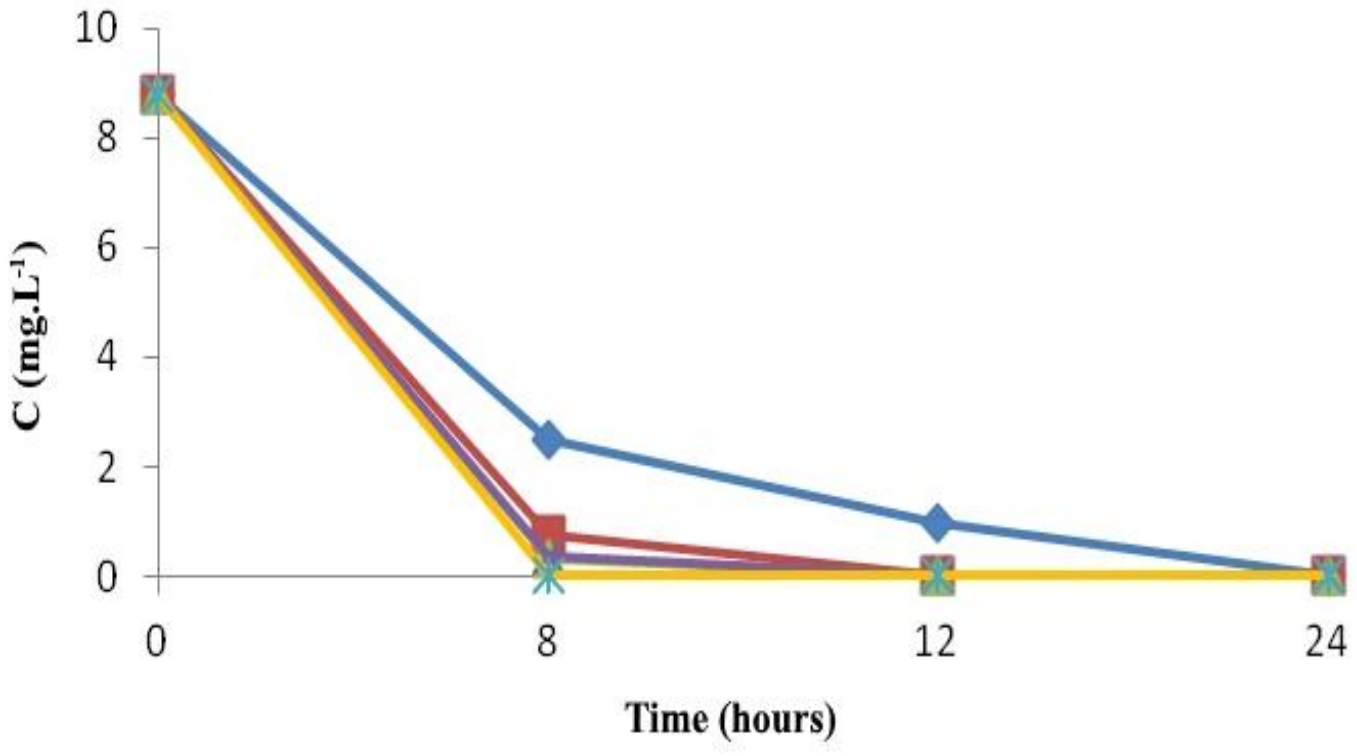

$\leadsto 0.1 \multimap 0.2 \leftarrow 0.3 \leftarrow 0.4 \div 0.5$ 
Fig.8 Value of solute concentration in the solid phase for a determined amount of active carbon at a given time

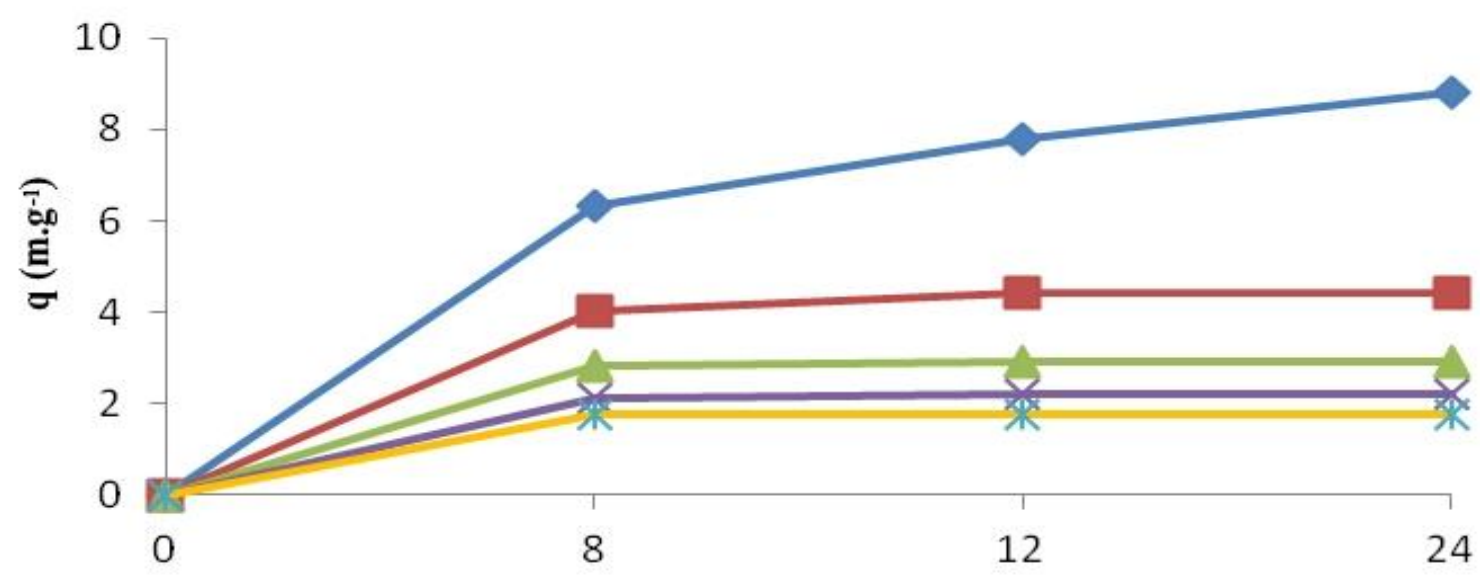

Time (hours)

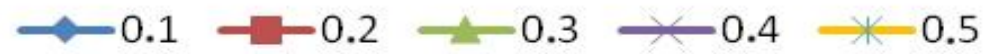

Fig.9 Comparison of the discoloration in relation to the control (1) by the bioadsorbent (2) and activated charcoal (3)

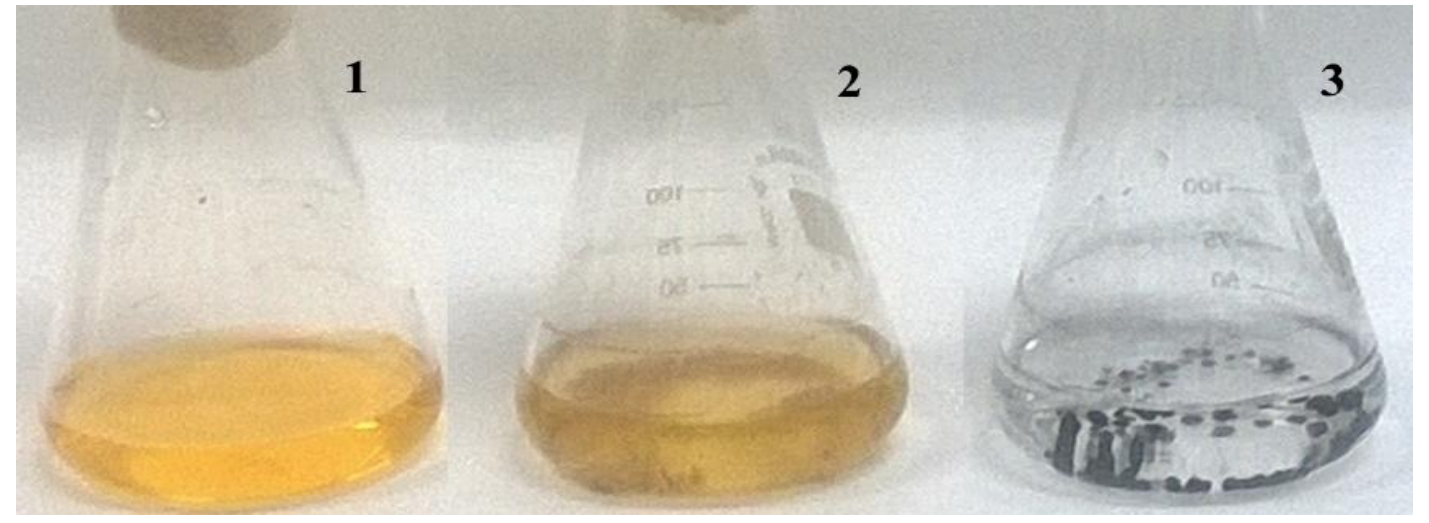

Agroindustrial residues in crop media in general should contain fermentable macronutrients (metabolically assimilated by microorganisms), with the proportions of carbon (energy) and nitrogen sources being the most significant, in addition, micronutrients and growth factors, in general, essential for microbial development (Meloet al., 2017). The physical-chemical adsorption of activated carbon and biological adsorbents through the biosorption technique in the discoloration of the azo dye Orange II presented in figures 3 and 6 , show that the use of biomass allowed a reduction of $66 \%$ discoloration for the concentration of $0.5 \mathrm{~g} . \mathrm{L}^{-1}$ of the biomass in $8 \mathrm{~h}$ of contact but when compared to activated carbon this demonstrated a greater efficiency of dye removal with $99 \%$ of discoloration at the same time of contact.

The dye removal efficiency increased with increasing concentrations of the adsorbent used. It is verified that for the fungal biomass figure 4 , the concentration of the dye decreased in the first 8 hours, stabilizing from that time. As for activated charcoal in the same period this reduced almost completely the concentration of 
the dye, reaching the total reduction at the end of the 24 hours of experiment figure 7.

In relation to the biosorption capacity "q", and the concentration of the solute adsorbed by the biomass $\mathrm{mg} . \mathrm{g}^{-1}$ at a given time (Figure 5), it was verified that the concentration of dye in the biosorbent fungi increased during the 24 hours tested presenting the best result of $2.26 \mathrm{mg} . \mathrm{g}^{-1}$ with $0.1 \mathrm{~g}$ of biomass, while the worst result was for the solution of $0.5 \mathrm{~g}$ of biomass with better performance in 8 hours with $1.17 \mathrm{mg} \cdot \mathrm{g}^{-1}$ showing a small reduction with over time, as for the other trials they obtained their best yields in the time of 12 hours.

The adsorbate adsorption adsorbent (q), with $8.8 \mathrm{mg} \cdot \mathrm{g}^{-1}$ dye per gram of charcoal after 24 hours, was also found to be the best adsorption capacity of the adsorbate. Some authors interpret that the maximum adsorption capacity decreases because the increase in adsorbent concentration has interference between the binding sites (Gadd and White, 1989).

Observing Figure 9, it can be seen visually that the activated carbon has superior capacity to remove the color of the orange dye II in relation to the fungal biomass. Activated charcoal is described with an effective adsorbent for processes for the treatment of effluent contaminants such as reactive dyes, basic dyes and azide dyes. However, it should be noted that this adsorbent presents a high cost of regeneration (Soares et al., 2014).

Although it has been demonstrated that the use of fungic biomass as biosorbents for the orange reactive azo dye II in effluent treatment processes is lower than the adsorbent activated carbon, the application of this biosorbent can be made possible by the reduction of production costs. Natural waste from industry and agriculture represents alternative sources widely available for the formulation of fermentative media for microorganism cultivation and thus provide a high economic potential (Aksu et al., 2010).

\section{Conflict of Interest}

The authors confirm that this article content has no conflict of interest.

\section{Acknowledgments}

The authors wish to thank the Brazilian Research Council (CNPq), Brazil, the Coordination for Improvement of Higher Level Education (CAPES), Brazil and the Foundation for Support of Science and Technology of the State of Pernambuco - FACEPE, Brazil. Special thanks are given to Catholic University of Pernambuco for making facilities and infrastructure available for the conduct of this research.

\section{References}

Aksu, Z., Ertugrul, S. and Donmez, G. 2010. Methylene Blue biosorption by Rhizopus arrhizus: Effects of SDS (sodium dodecylsulfate) surfactant on biosorption properties. Chemical Engineering Journal.158: 474-481.

Ambrósio, S. T., Júnior, J. C. V., Silva, C. A. A., Okada, K., Nascimento, A. E., Longo, R. L. and Campos-takaki, G. M. (2012) A Biosorption Isotherm Model for the Removal of Reactive Azo Dyes by Inactivated Mycelia of Cunninghamella elegans UCP542. Journal Molecules. 17:452-462.

Banat, I. M., Nigam, P., Singh, D. and Marchant, R. 1996. Microbial descolorization of textile-dye-containing effluents: a review. Bioresour. Technol. 58(3): 217-227.

Barreto, W. J., Bernardino, N. D.and Afonso, R. 2011. Biodegradação de uma mistura de corantes têxteis usando o fungo ganodermasp: Um estudo cinético. Química nova. 34(4): 568-572.

Beydilli, M. I.andPavlostathis, S. G. 2005. Decolorization Kinetics of the azo dye Reactive Red 2 under methanogenic conditions: effect of long-term culture acclimation. Biodegradation. 16(2): 135146.

Chang, J.S. and Kuo, T.S. 2000. Kinetics of 
bacterial decolorization of azo dye with Escherichia coli $\mathrm{NO}_{3}$. Bioresource Technology. 75:107-111.

Conceição, V. M. and Freire, F. B. 2013. Descoloração de efluente têxtil sintético em reator UASB seguido de adsorção em bagaço de cana-de-açúcar. Revistatecnológica-Maringá. 22: 109-122.

Deepika, R., Sathyabama, N., Sankareswaran, M., Anbalagan, S., Vinayaga, M. D. and Kamalakkannan, V. 2014. Bioremediation of textile effluent with Aspergillus niger based silver nanoparticles and it's field trial. Journal of Environmental Science, Computer Science and Engineering \& Technology. 3(3):1156-1171.

Faraco, V., Pezzella, C., Giardina, P., Piscitelli, A. Vanhulle, S. and Sannia, G. 2009. Decolourization of textile dyes by the white-rot fungi Phanerochaete chrysosporium and Pleurotus ostreatus. Journal Chem. Technol. Biotechnol. 84:414-419.

Fávere, V. T., Riella, H. G. and Rosa, S. 2010. Cloreto de N-(2-Hidroxil) propil-3-trimetil amônio quitosana como adsorvente de corantes reativos em solução aquosa. Química nova, 33(7): 1476-1481.

Gadd, G. M. and White, C. 1989. Removal of thorium from simulated acid process streams by fungal biomass. Biotechnology. Bioeng, 33: 592-597.

Gupta, N., Tripathi, A. K. and Harsh, N. S. K. 2011. Bioremediation of cotton-textile effluent using fungi. BEPLS- Bulletin of Environment, Pharmacology \& Life Sciences. 1(1): 15-19.

Melo, T. L., Melo, V. A. and Alves, C. A. 2017.
Produção de lacase utilizando planejamen to fatorial em meios contendo resíduos agro-industriais. Engevista, 19(3): 759-773.

Mielgo, I., Moreira, M.T., Feijoo, G.andLema, J. M. 2001. A packed-bed fungal bioreactor for the continuous decolourisation of azodyes (orange II). Journal of Biotechnology. 89, 99-106.

Peixoto, F. P., Marinho, G. and Rodrigues, K. 2013. Corantes têxteis: Uma revisão. HOLOS. 5, 98-106.

Salvador, T., Marcolino, L. H. And Zamora, P. P. 2012. Degradação de corantes têxteis e remediação de resíduos de tingimento por processo fenton, foto-fenton e eletro-fenton. Química nova. 35(5): 932-938.

Santaella, S. T., Silva, F. C. G., Gadelha, D. A. C.,Costa, K. O., Aguiar, R., Arthaud, I. D. B. and Leitão, R. C. 2009. Tratamento de efluentes de refinaria de petróleo em reatores com Aspergillus niger. Engenharia Sanitaria Ambiental. 14(1): 139-148.

Singh, R. P., Singh, P. K. and Singh, R. L. 2014. Bacterial decolorization of textile azo dye acid orange by Staphylococcus hominis RMLRT03. International journal of toxicology. 21(2): 60-166.

Soares, P. A., Silva, T. F., Manenti, D. R., Souza, S. M., Boaventura, R. A. and Vilar, V. J. 2014. Insights into real cotton-textile dyeing wastewater treatment using solar advanced oxidation processes. Environmental Science and Pollution Research.21 (2):932-945.

Souza, C. R. L. and Zamora, P. P. 2005. Degradação de corantes reativos pelosistema ferrometálico/peróxido de hidrogênio. Química nova. 28(2): 226-228.

\section{How to cite this article:}

Lefferson C. Gomes, Paulo H. da Silva, Ana P. Melo bione, Amanda B. Lins, Tainã C.S. Fonseca, Rosileide F.S. Andrade, Carlos A. da Silva and Galba M. Campos-Takaki. 2017. Biotechnological Potential of Aspergillus niger UCP 1353 and the Use of Activated Coal on the Discoloration of Dye Orange II. Int.J.Curr.Microbiol.App.Sci. 6(12): 2716-2727. doi: https://doi.org/10.20546/ijcmas.2017.612.315 